\title{
IDENTIFIKASI KECERDASAN MAJEMUK SLIM-N-BIL PADA MAHASISWA PRODI PENDIDIKAN INFORMATIKA ANGKATAN 2013 UNIVERSITAS TRUNOJOYO MADURA
}

\author{
Ariesta Kartika Sari \\ Universitas Trunojoyo Madura \\ Bangkalan, Indonesia \\ ariestakartika@ymail.com
}

\begin{abstract}
Abstrak
Anak merupakan aset orangtua yang memiliki kemampuan sangat luas. Banyak potensi yang terpendam dalam dirinya seperti halnya lautan yang luas beserta banyaknya kekayaan alam di dalamnya. Chatib (2014:87) menyebut potensi terpendam dalam diri anak sebagai HARTA KARUN adalah kecerdasan Majemuk atau multiple Intelligence. Mahasiswa Program studi pendidikan informatika pastilah memiliki keanekaragaman latar belakang budaya, minat, potensi, dan kecerdasan. Melalui penerapan pembelajaran yang tepat, pembelajaran yang sesuai dengan karakteristiknya maka diharapkan akan dapat mengembangkan potensi masing-masing kecerdasan pada mahasiswa.

Dalam penelitian ini, peneliti akan melakukan identifikasi terhadap mahasiswa prodi pendidikan informatika angkatan tahun 2013. Identifikasi tersebut akan dilakukan dengan menggunakan kriteria 8 kecerdasan yang telah dikembangkan oleh Dr. Howard Gardner yaitu kecerdasan majemuk (Multiple Intelligence) SLIM-N-BIL. Kecerdasan majemuk (Multiple Intelligence) SLIM-N-BIL terdiri atas: kecerdasan Spasial-Visual (S), kecerdasan Linguistik-Verbal (L), kecerdasan Interpersonal (I), kecerdasan Musikal-ritmik (M), kecerdasan Naturalis (N), kecerdasan Badan-Kinestetik (B), kecerdasan Intrapersonal (I), kecerdasan Logis-Matematis (L). Identifikasi terhadap 100 mahasiswa menghasilkanbahwa kecerdasan yang mendominasi berkembang dalam mahasiswa program studi pendidikan informatika antara lain: kecerdasan interpersonal (I), kecerdasan Naturalis (N), Kecerdasan Intrapersonal, dan selebihnya sebanyak 39\% dari 100 mahasiswa memiliki beberapa kecerdasan yang telah berkembang secara dominan (yang kami masukkan dalam kategori "gabungan").
\end{abstract}

Kata kunci: Kecerdasan majemuk, SLIM-N-BIL. 


\begin{abstract}
Kids are assets of parents who have a very broad capability. Many potentiall atentint heir self as well as a vast ocean and its many natural resources there in. Chatib (2014: 87) calls the latent potential within the child as TREASURE are multiple Intelligence. Students informatics education study program must have a diversity of cultural backgrounds, interests, potential and intelligence. Through the application of appropriate learning, learning in accordance witht the characteristics it will hopefully be able to developthe potential of each student intelligence.

In this study, researchers will identify the student of 2013th in informatics education department. Such identification will be carried out using eight criteria of intelligence that has been developed by Dr. Howard Gardner's multiple intelligences namelySLIM-N-BIL. Multiple intelligencesSLIM-N-BILconsists of: SpatialVisual (S) Intelligence, Linguistic-Verbal Intelligence (L), Interpersonal Intelligence (I), Musical-Rhythmic Intelligence (M), Naturalis Intelligence (N), Body-Kinesthetic Intelligence (B), Intrapersonal Intelligence (I), Logical-Mathematical Intelligence (L). Identification of the 100 students giving result that intelligence that dominates developin students of informatics educational include: interpersonal Intelligence, Naturalis (N)Intelligence, Intrapersonal Intelligence, andrest as much as $39 \%$ of the 100 students had some intelligencethat has developed predominantly (which we include in thecategory of "combined").
\end{abstract}

Keywords: multiple intelligences namely SLIM-N-BIL 


\section{PENDAHULUAN}

Gardner dalam chatib (2014:87-88) menyebutkan bahwa setiap anak punya kecenderungan kecerdasan dari sembilan kecerdasan, yaitu cerdas bahasa (linguistik), cerdas matematis-logis (kognitif), cerdas gambar dan ruang (visual-spasial), cerdas musik, cerdas gerak (kinestetik), cerdas bergaul (interpersonal), cerdas diri (intrapersonal), cerdas alam, dan cerdas eksistensial.

Kenyataan secara umum yang berlaku pada masyarakat bahwa kecerdasan hanya diukur dari tingkat IQ. Hasil temuan Gunawan (2012:151) banyak orang yang berpendapat bahwa kata "cerdas" atau "kecerdasan" umumnya diartikan beberapa sebagai berikut : (1) lulus dengan IP yang tinggi, (2) pintar cari uang, (3) mampu sekolah sampai S2 ataupun S3, (4) saat sekolah nilai ujiannya selalu mendapat angka 10, (5) menjadi juara kelas, (6)IQ yang di atas rata-rata, (7) mengambil jurusan ilmu eksakta, (8) mampu menghitung cepat, (9) mampu bicara dalam banyak bahasa, (10) bisa masuk perguruan tinggi favorit, (11) sering mendapat beasiswa, dan masih banyak lagi.

Memang dahulu, pada tahun 1905, Alfred Binet membuat tes IQ hanya untuk mengukur kecerdasan anak dari dua ranah yang masih sempit, yaitu kemampuan verbal/linguistik/bahasa dan logikamatematika, kemudian merangkum dalam sebuah angka yang disebut angka IQ. Anak yang pandai menari, menggambar, bersosialisasi, dan sebagainya masih belum terdeteksi bahwa mereka juga memiliki kecerdasan (Chatib, 2014:94). Setelah adanya karya Howard Gardner tentang teori kecerdasan majemuk (multiple Intelligence) maka kurang bijaksana jika menyimpulkan kecerdasan seorang anak hanya berdasarkan pada tes angka-angka IQ nya saja. Teori kecerdasan majemuk inilah yang berani menyatakan bahwa kecerdasan seseorang sudah tidak lagi dapat ditentukan oleh angkaangka IQ.

Mahasiswa Program studi pendidikan informatika pastilah memiliki keanekaragaman latar belakang budaya, minta, potensi, dan kecerdasan. Melalui penerapan pembelajaran yang tepat, pembelajaran yang sesuai dengan karakteristiknya maka diharapkan akan dapat mengembangkan potensi masing-masing kecerdasan pada mahasiswa.

Untuk menuju pengembangan pembelajaran dalam rangka peningkatan kualitas lulusan mahasiswa, maka dipandang perlu adanya tinjauan berbasis kecerdasan majemuk terhadap mahasiswa di prodi pendidikan Informatika. Dengan mengetahui karakteristik kecerdasan mahasiswa, maka para dosen diharapkan dapat dengan mudah menerapkan strategi pembelajaran yang sesuai dengan kecerdasan mahasiswa. Bahkan, dosen dapat menerapkan satu strategi tertentu yang dapat bermanfaat untuk meningkatkan salah satu tipe kecerdasan majemuk yang belum berkembang.

Dalam penelitian ini, peneliti akan melakukan identifikasi terhadap mahasiswa prodi pendidikan informatika angkatan tahun 2013. Identifikasi tersebut akan dilakukan dengan menggunakan kriteria 8 kecerdasan yang telah dikembangkan oleh Dr. Howard Gardner yaitu kecerdasan majemuk (Multiple Intelligence) SLIM-N-BIL. Kecerdasan majemuk (Multiple Intelligence) SLIM-N-BIL terdiri atas: kecerdasan Spasial-Visual (S), kecerdasan Linguistik-Verbal (L), kecerdasan Interpersonal (I), kecerdasan Musikal-ritmik (M), kecerdasan Naturalis (N), kecerdasan Badan-Kinestetik (B), kecerdasan Intrapersonal (I), kecerdasan Logis-Matematis (L).

Kecerdasan Majemuk SLIM-N-BIL merupakan delapan kecerdasan majemuk dari sembilan kecerdasan majemuk (Multiple Intelligence) Howard Gardner. Kecerdasan Majemuk SLIM-N-BIL merupakan singkatan 
dari Kecerdasan majemuk (Multiple Intelligence) yang terdiri atas: kecerdasan Spasial-Visual (S), kecerdasan LinguistikVerbal (L), kecerdasan Interpersonal (I), kecerdasan Musikal-ritmik (M), kecerdasan Naturalis (N), kecerdasan Badan-Kinestetik (B), kecerdasan Intrapersonal (I), kecerdasan Logis-Matematis (L). Masing-masing kecerdasan majemuk SLIM-N-BIL akan diulas ringkas sebagai berikut (DePorter, 2014:138139):

1) Spasial-Visual - berpikir dalam Citra dan gambar.

Melibatkan kemampuan untuk memahami hubungan ruang dan Citra mental, dan secara akurat mengerti dunia visual.Halhal yang terkait antara lain: menggambar, mensketsa, mencorat-coret, visualisasi, citra, grafik, desain, tabel, seni, video, film, ilustrasi.

2) Lingustik-Verbal - berpikir dalam katakata.

Mencakup kemahiran dalam berbahasa untuk berbicara, menulis, membaca, menghubungkan, dan menafsirkan.

Hal-hal yang terkait antara lain: kata-kata, berbicara, menulis, bercerita, mendengarkan, buku, kaset, dialog, diskusi, puisi, lirik, mengeja, bahasa asing, surat, e-mail, makalah, esai.

3) Interpersonal - berpikir lewat berkomunikasi dengan orang lain.

Ini mengacu pada keterampilan manusia, yaitu dapat dengan mudah membaca, berkomunikasi, dan berinteraksi dengan orang lain.

Hal-hal yang terkait antara lain: memimpin, mengorganisasi, berinteraksi, berbagi, menyayangi, berbicara, sosialisasi, manipulasi, menjadi pendamai, permainan kelompok, klub, teman-teman, kelompok kerja sama.

4) Musikal-ritmik - berpikir dalam irama dan melodi.
Hal-hal yang terkait antara lain: menyanyi, bersenandung, mengetukngetuk, irama, melodi, kecepatan, warna, nada, alat musik, rima.

5) Naturalis - berpikir dalam acuan alam. Kecerdasan Naturalis merupakan pendatang baru dalam kecerdasan Gardner. Kecerdasan ini menyangkut pertalian seseorang dengan alam, yang dapat melihat hubungan dan pola dalam dunia alamiah dan mengidentifikasi dan berinteraksi dengan proses alami.

6) Badan - Kinestetik (berpikir melalui sensasi dan gerakan fisik)

Kecerdasan badan-kinestetik merupakan kemampuan untuk mengendalikan dan menggunakan badan fisik dengan mudah dan cekatan. Aktivitas yang sering dilakukan antara lain: menari, berlari, melompat,menyentuh, menciptakan, mencoba, mensimulasikan, merakit/membongkar, bermain drama, permainan, atau indera.

7) Intrapersonal (berfikir secara reflektif) Kecerdasan intrapersonal berhubungan dengan kesadaran reflektif terkait perasaan dan pemikiran. Aktivitas yang sering dilakukan antara lain: berfikir, meditasi, bermimpi, berdiam diri, mencanangkan tujuan, refleksi, merenung, membuat jurnal, menilai diri, waktu menyendiri, proyek yang dirintis sendiri.

8) Logis - matematis (Berfikir dengan penalaran)

Melibatkan pecahan masalah secara logis dan ilmiah dan kemampuan matematis.

Aktivitas yang sering dilakukan antara lain: bereksperimen, bertanya berhitung, menghitung, logika deduktif dan induktif, mengorganisasikan, fakta, tekateki, skenario.

Dengan demikian, judul penelitian yang diangkat adalah Identifikasi Kecerdasan Majemuk SLIM-N-BIL pada Mahasiswa 
Prodi Pendidikan Informatika Angkatan Tahun 2013 Universitas Trunojoyo Madura

Tujuan dalam penelitian ini antara lain;

1. Mengidentifikasi kecerdasan majemuk SLIM-N-BIL yang dimiliki mahasiswa prodi pendidikan informatika angkatan tahun 2013 di UniversitasTrunojoyo Madura

2. Mendeskripsikan upaya-upaya pengembangan terhadap masingmasing kecerdasan majemuk SLIM-NBIL dalam pembelajaran

Beberapa manfaat yang diperoleh adalah sebagai berikut;

1. Hasil identifikasi terhadap kecerdasan majemuk mahasiswa di prodi pendidikan informatika Universitas Trunojoyo Madura, terutama angkatan tahun 2013, diharapkan dapat memberikan informasi terkait kondisi awal kecerdasan potensi mahasiswa mana saja yang mendominasi/sudah berkembang, sehingga dosen dapat menerapkan strategi/model pembelajaran yang tepat untuk meningkatkan kualitas hasil belajar.

2. Hasil identifikasi terhadap kecerdasan majemuk mahasiswa program studi pendidikan informatika Universitas Trunojoyo Madura diharapkan juga memberikan informasi terkait kecerdasan atau potensi mana saja yang dianggap belum berkembang, sehingga dosen dapat menerapkan strategi/model pembelajaran yang tepat untuk mengembangkan kecerdasan tersebut.

3. Deskripsi upaya pengembangan kecerdasan majemuk SLIM-N-BIL diharapkan dapat bermanfaat bagi dosen/pendidik sebagai bahan pertimbangan dalam menyusun model/strategi pembelajarannya.

\section{METODE PENELITIAN}

Penelitian ini bertujuan untuk fenomena-fenomena terkait kecerdasan majemuk yang dimiliki oleh mahasiswa prodi pendidikan informatika. Penelitian ini termasuk penelitian kuantitatif bersifat noneksperimen dengan metode deskriptif. Dengan demikian, penelitian ini merupakan penelitian deskriptif kuantitatif. Oleh karena itu, jenis penelitian ini adalah penelitian deskriptifkuantitatif.

Populasi penelitian ini adalah seluruh mahasiswa program studi pendidikan informatika yang berasal dari angkatan 2013 sejumlah 143 mahasiswa. Sedangkan sampel penelitian diambil sebanyak 100 mahasiswa sesuai dengan ketentuan table penentuan jumlah sampel dari populasi tertentu dengan taraf kesalahan 5\% (Sugiyono, 2014:71) .

Instrumen yang digunakan dalam penelitian ini berupa Tes Kecenderungan Kecerdasan Majemuk SLIM-N-BILyang berbentuk skala Likert. Te s ini akan diisi oleh sampel penelitian. Tes Kecenderungan Kecerdasan Majemuk (TKKM) ini berisi sejumlah pernyataan tertulis yang digunakan untuk memperoleh informasi dari sampel penelitian terkait karakteristik 8 kecerdasan majemuk. Tes yang digunakan mengadopsi dari penyataan tes kecerdasan majemuk yang disusun oleh Tim @Psikologi ID dalam bukunya berjudul Who Am I ?(2013: 15-27). Dengan demikian instruments ini tidak perlu dilakukan validasi lagi. Sedangkan teknik/metode yang digunakan dalam pengambilan data penelitian in iadalah teknik tes diagnostik. Disebut tes diagnostic karena tes ini bersifat untuk menganalisis kecenderungan karakteristik kecerdasan majemuk yang dimiliki oleh sampel penelitian. 
HASIL DAN PEMBAHASAN

\section{Rekapitulasi Tes Kecerdasan Majemuk SLIM-N-BIL}

Penelitian ini mengambil data dari 100 sampel yang berasal dari mahasiswa program studi Pendidikan Informatika angkatan tahun 2013, yang mana saat ini menduduki semester 5. Subjek penelitian mengisi angket (terlampir) sesuai dengan penilaiannya terhadap diri sendiri. Pada Tes masing-masing kecerdasan memiliki 10 pernyataan. jika pernyataan tersebut sesuai dengan pribadinya maka subjek dapat memberi tanda centang pada jawaban "Ya", sebaliknya jika pernyataan tersebut tidak sesuai dengan pribadinya maka subjek dapat memberi tanda centang pada jawaban "Tidak". Jawaban "Ya" bernilai "1" dan Jawaban "Tidak" bernilai " 0 ". Kesimpulan kecerdasan dominan yang dimiliki setiap subjek penelitian ditentukan oleh jumlah skor terbesar mana yang diperoleh subjek tersebut dalam angket kecerdasan majemuk.

Setelah hasil tes dianalisis diperoleh data yang disajikan pada Tabel 4.1 di bawah ini;

Tabel 1. Rekapitulasi Tes Kecerdasan Majemuk SLIM-N-BIL pada Mahasiswa Program Studi Pendidikan Informatika Angkatan 2013

\begin{tabular}{|l|c|}
\hline Kecerdasan & \% \\
\hline kecerdasan Spasial-Visual (S) & $9 \%$ \\
\hline kecerdasan Linguistik-Verbal (L) & $0 \%$ \\
\hline kecerdasan Interpersonal (I) & $16 \%$ \\
\hline kecerdasan Musikal-ritmik (M) & $4 \%$ \\
\hline kecerdasan Naturalis (N) & $13 \%$ \\
\hline kecerdasan Badan-Kinestetik (B) & $2 \%$ \\
\hline kecerdasan Intrapersonal (I) & $12 \%$ \\
\hline kecerdasan Logis-Matematis (L) & $5 \%$ \\
\hline Gabungan & $39 \%$ \\
\hline Jumlah & $100 \%$ \\
\hline
\end{tabular}

Tampak dari Tabel 1 di atas bahwa kecerdasan yang mendominasi berkembang dalam mahasiswa program studi pendidikan informatika antara lain: kecerdasan interpersonal (I), kecerdasan Naturalis (N),
Kecerdasan Intrapersonal, dan selebihnya sebanyak 39\% dari 100 mahasiswa memiliki beberapa kecerdasan yang telah berkembang secara dominan (yang kami masukkan dalam kategori "gabungan"), selengkapnya dapat dilihat pada lampiran. Hasil analisis kecerdasan tersebut di atas dapat disajikan secara diagram lingkaran pada Gambar 1.

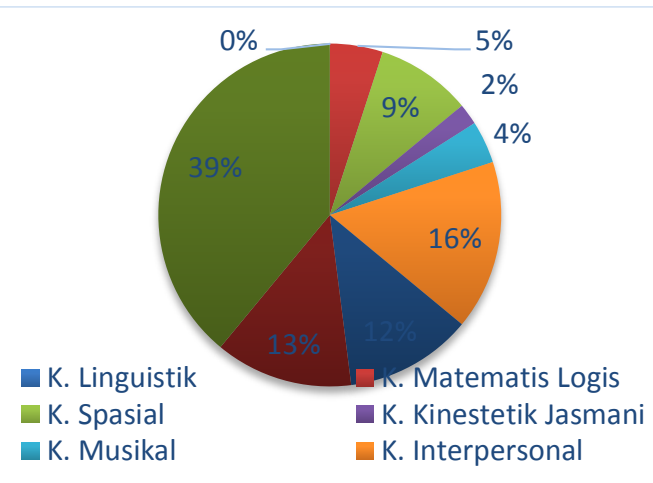

Gambar 1. Diagram Kecerdasan Majemuk SLIM-N-BILL Mahasiswa Prodi

Pendidikan Informatika Angkatan 2013

\section{Upaya-Upaya Pengembangan terhadap Masing-Masing Kecerdasan Majemuk SLIM-N-BIL}

Menurut buku Pembelajaran Quantum dan Optimalisasi Kecerdasan (Kosasih, Nandang dan Sumarna, Dede, 2013: 182-184) mengutarakan beberapa upaya untuk meningkatkan kemampuan peserta didik dalam mengembangkan kecerdasan majemuknya dalam pembelajaran sesuai dengan kecerdasan yang dimiliki. Gunawan, adi W (2012: 246249) juga mengungkapkan beberapa cara untuk melatih dan mengembangkan kecerdasan majemuk dalam bukunya Genius Learning Strategi, antara lain bahwa pendidik perlu menyediakan waktu yang cukup bagi anak didik untuk melakukan refleksi dan berfikir. Hal ini dilakukan sebagai pada pendidik dalam melatih dan mengembangkan kecerdasan tipe Intrapersonal dan masih banyak lagi.

Berdasarkan studi literasi beberapa buku pustaka tersebut, dengan demikian peneliti mendeskripsikan beberapa teknik yang 
dapat digunakan oleh pendidik dalam pembelajarannya sebagai upaya untuk melatih dan mengembangkan kecerdasan majemuk SLIM-N-BIL.

a) Kecerdasan Spasial-Visual (S)

1. Dosen dapat menyajikan materi melalui media gambar, sehingga mahasiswa memahami materi melalui gambar tersebut.

2. Dosen dapat meminta mahasiswa untuk menggambarkan konsep yang telah difahami, misalkan melalui Mindmapping.

3. Dosen meminta mahasiswa untuk membuat prakata

4. Dosen dapat mengkombinasikan pembelajarannya dengan adanya permainan bongkar pasang dengan puzzel, lego, dan lainnya.

5. Dosen sering menggunakan media atau alat peraga

6. Dosen dapat memberikan tugas yang melibatkan pemanfaatan gambar atau poster

b) Kecerdasan Linguistik-Verbal (L)

1. Dosen mengajar mahasiswa untuk berdialog, berdiskusi, debat, atau colaborativelearning.

2. Dosen menerapkan metode membaca cerita. Membaca cerita bisa dilakukan oleh dosen atau teman sebaya mahasiswa.

3. Dosen menerapkan metode bermain peran.

4. Dosen meminta mahasiswa untuk membuat dan mengisi buku harian atau menulis surat.

5. Dosen memberi kesempatan pada mahasiswa untuk menjelaskan pengertian sebuah konsep dengan menggunakan bahasanya sendiri.

6. Dosen mengajarkan dan meminta mahasiswa untuk menyusun sebuah presentasi atau makalah c) Kecerdasan Interpersonal (I)

1. Dosen menugaskan mahasiswa dalam kerja kelompok

2. Dosen membentuk kelompok belajar baik secara acak maupun dengan kriteria tertentu

3. Mengadakan tutor sebaya

4. Menerapkan diskusi dalam penyelesaian masalah

5. Dosen mengajarkan bagaimana cara bersikap dan bekerjasama dengan rekannya

6. Dosen menetapkan aturan di kelas secara bersama-sama dengan mahasiswa

d) Kecerdasan Musikal-ritmik (M)

1. Dosen mengajak mahasiswa untuk bermain dengan musik/lagu dengan cara mengubah lirik, nada, tempo, volume atau keras-lembut, sebagai bagian dari eksplorasi materi ke dalam dunia musik

2. Dosen mengajak mahasiswa mendengarkan musik

3. Dosen mengajak mahasiswa memainkan berbagai jenis lagu atau musik dan meminta mahasiswa untuk menjelaskan apa yang mereka rasakan.

4. Dosen menggunakan musik sebagai tanda waktu dalam mengerjakan tugas, untuk memulai dan untuk mengakhiri sesi pembelajaran

5. Dosen menggunakan musik sebagai pengubah suasana dan untuk meningkatkan energi relaksasi

6. Dosen menggunakan musik untuk membantu mengingat materi

e) Kecerdasan Naturalis (N)

1. Menjadikan alam terbuka sebagai tempat belajar

2. Bersama-sama, memelihara tanaman di sekitar lingkungan belajar 
3. Dosen bersama mahasiswa melakukan percobaan-percobaan

4. Mempelajari kejadian alam seperti gempa bumi, banjir, dan sebagainya serta apa implikasinya bagi umat manusia

5. Mempelajari pengaruh perbuatan manusia terhasap alam baik pengaruh positif maupun yang negatif, langsung maupun tidak langsung

6. Melakukan perjalanan ke lingkungan, misalkan ke kebun raya atau taman safari

f) Kecerdasan Badan-Kinestetik (B)

1. Dosen menyediakan kegiatan agar mahasiswa dapat bergerak

2. Dosen membuat model kegiatan yang memerlukan keterampilan motorik halus

3. Berikan rehat fisik secara rutin di tengah-tengah pembelajaran, bisa dalam bentuk permainan.

4. Dosen memberi kesempatan pada mahasiswa untuk mengungkapkan pemahamannya dengan membuat atau memanipulasi objek

5. Lakukan rehearsal melalui gerakan, permainan peran, simulasi atau kegiatan praktis lainnya

6. Dosen memberi kesempatan pada mahasiswa untuk membuat montase atau mural

g) Kecerdasan Intrapersonal (I)

1. Dosen memberikan kesempatan pada mahasiswa untuk belajar mandiri

2. Dosen menciptakan suasana kelas yang tenang agar mahasiswa dapat bekerja sendiri.

3. Dosen menyediakan waktu yang cukup untuk melakukan refleksi dan berfikir

4. Dosen perlu memperhatikan dan menghargai perasaan dan motivasi sebagai bagian dari kesempatan berbagi cerita, pengalaman, dan kesan

5. Melibatkan peta pikiran dan tembok aspirasi/mural

6. Dosen perlu memiliki sikap sabar dan menjawab pertanyaan yang bersifat terbuka dan filosofis (membutuhkan jawaban mendalam)

h) Kecerdasan Logis-Matematis (L)

1. Dosen perlu mengajarkan metode pemecahan masalah yang dapat digunakan dalam berbagai disiplin ilmu dan keadaan.

2. Dosen meminta mahasiswa untuk menggunakan diagram dalam menyajikan data

3. Dosen sering-sering menggunakan angka atau permainan yang melibatkan angka dan logika

4. Dosen mengarahkan mahasiswa untuk mencari hubungan antara matematika dan praktiknya dalam kehidupan sehari-hari.

5. Dosen perlu mengajarkan cara melakukan pengkategorian, klasifikasi, prioritas, dan keterampilan memprediksi.

6. Dosen perlu melibatkan permainan yang dapat meningkatkan kemampuan berfikir lateral, misalnya dengan memberikan lateralthinkingpuzzel

\section{KESIMPULAN DAN SARAN Kesimpulan}

Berdasarkan hasil analisis terhadap angket tes kecerdasan majemuk terhadap 100 subjek penelitian, diperoleh hasil ;

a) kecerdasan yang mendominasi berkembang dalam mahasiswa program studi pendidikan informatika antara lain: kecerdasan interpersonal (I) sebanyak $16 \%$, kecerdasan Naturalis $(\mathrm{N})$ sebanyak $13 \%$, Kecerdasan Intrapersonal (I) 
sebanyak $12 \%$, dan selebihnya sebanyak $39 \%$ dari 100 mahasiswa memiliki gabungan beberapa kecerdasan yang telah berkembang secara dominan

b) beberapa kecerdasan yang perlu lebih dikembangkan antara lain: kecerdasan linguistik-Verbal (L), kecerdasan BadanKinestetik (B), dan yang terpenting bagi mahasiswa program studi pendidikan informatika adalah kecerdasan Logismatematis.

\section{Saran}

Dosen perlu mempelajari dan mencoba beberapa teknik upaya-upaya yang telah dijabarkan sebagai bentuk dalam pengembangan kecerdasan majemuk mahasiswa. Dengan demikian, lulusan mahasiswa prodi Pendidikan Informatika menjadi insan yang berkualitas

\section{DAFTAR PUSTAKA}

Arikunto, suharsimi. 2002. Prosedur Penelitian Suatu Pendekatan Praktek. Jakarta: PT Rineka Cipta.

Chatib, munif. 2014. Orangtuanya Manusia: Melejitkan Potensi dan Kecerdasan dengan Menghargai Fitrah Setiap Anak. Bandung: PT Mizan Pustaka.

Chomaria, Nurul. 2014. Tes Kepribadian Remaja Muslim. Surakarta: Al-Qudwah Publishing.

DePorter, Bobbi., Mark Reardon,\&Sarah Singer-Nourie. 2014. Quantum Teaching. Bandung: PT Mizan Pustaka.

Erlin ladyawati dan Oktavia. 2014. penelitiannya dengan judul "Identifikasi Kecerdasan Majemuk pada Siswa Sekolah Dasar"

Gunawan, Adi W. 2012. Born to be a Genius. Jakarta: PT Gramedia Pustaka Utama.
Gunawan, Adi W. 2012. Genius Learning Strategy. Jakarta: PT Gramedia Pustaka Utama.

Joko Widodo dkk .2013. Penerapan strategi identifikasi berbasis kecerdasan majemuk pada siswa kelas X-A SMAN 1 Gemolong tahun ajaran 2011/2012. Jurnal pendidikan bahasa dan sastra.

Kosasih, N. \& Dede Sumarna. 2013. Pembelajaran Quantum dan Optimalisasi Kecerdasan. Bandung: Alfabeta.

Novita Sari, Ade Rakhman. 2014. How Great is Your Personality?. Yogyakarta: Cemerlang Publishing.

Siberman, Melvin L. 2014. Active Learning; 101 cara Belajar Siswa Aktif. Bandung: Nuansa Cendekia.

Sugiyono. 2014. Statistika untuk Penelitian. Alfabeta:Bandung.

@PsikologiID. 2013. Who am I ? Personality Test (kenali dan upgrade dirimu). Jakarta: PT Tangga Pustaka 